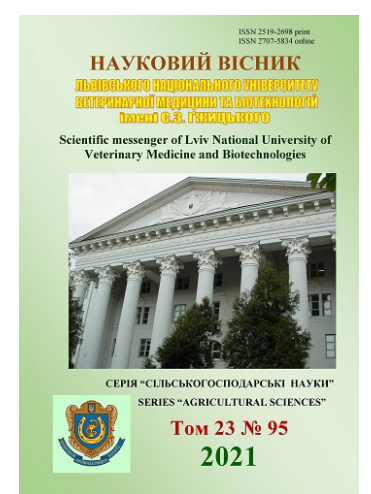

Науковий вісник Дьвівського національного університету ветеринарної медицини та біотехнологій імені С.3. Гжицького. Серія: Сільськогосподарські науки

\author{
Scientific Messenger of Lviv National University \\ of Veterinary Medicine and Biotechnologies. \\ Series: Agricultural sciences
}

doi: 10.32718/nvlvet-a9518

https://nvlvet.com.ua/index.php/agriculture

\title{
Assessment of the quality of the southern Bug waters within the Khmelnytsky region and biotechnological ways to solve their purification
}

\author{
O. O. Malashchuk, O. P. Rudenko
}

Stepan Gzhytskyi National University of Veterinary Medicine and Biotechnologies Lviv, Ukraine

Article info

Received 10.06.2021

Received in revised form 12.07.2021

Accepted 13.07.2021

Stepan Gzhytskyi National University of Veterinary Medicine and Biotechnologies Lviv, Pekarska Str., 50, Lviv, 79010, Ukraine. Tel.: +38-096-813-07-93 E-mail: rudenko.olga86@gmail.com
Malashchuk, O. O., \& Rudenko, O. P. (2021). Assessment of the quality of the southern Bug waters within the Khmelnytsky region and biotechnological ways to solve their purification. Scientific Messenger of Lviv National University of Veterinary Medicine and Biotechnologies. Series: Agricultural sciences, 23(95), 122-127. doi: 10.32718/nvlvet-a9518

Water resources are the national wealth of each state, an important natural resource, and determine the development opportunities of most sectors of the economic complex of Ukraine. The Southern Bug River is the largest river, the basin of which is completely located in Ukraine. Due to the intensive growth of anthropogenic impact on the studied reservoir and the economic use of its resources, the quality of water in it has significantly decreased. To improve the quality of water in rivers, it is optimal to use biotechnological methods, which provide many opportunities for effective solutions to issues related to monitoring, assessment, and treatment of polluted watercourses. The aim of our study was to assess water safety, the current ecological status of the Southern Bug River within the Khmelnytsky region in three areas (Maryanivske Reservoir, Kopystyn, Shchedrivske Reservoir) and use in domestic needs, with analysis of potential risks to human health, development of new biotechnological and improvement of existing measures to improve water supply. The experimental part of the work was performed on the basis of the Khmelnytsky Regional Department of Water Resources in the laboratory at the address Khmelnytsky, st. Soborna, 29. We conducted a chemical assessment of the Southern Bug River on three indicators: salt composition (II), tropho-saprobiological (I2), and specific toxic substances (13). Research of river waters was carried out in order to control the MPC (maximum permissible concentrations) of substances for use in household and food needs of the population and to propose biotechnological methods of river water purification within the Khmelnytsky region. According to our research on hydrochemical characteristics, the water contained elevated levels of $\mathrm{NH}_{4}, \mathrm{NO}_{2}, \mathrm{NO}_{3}, \mathrm{PO}_{4}$, the average values of $\mathrm{HSC}$ (chemical oxygen demand) exceeded the MPC in all areas by 2 to 5 times. This may be due to exposure to organic compounds of natural origin. The content of nitrites, nitrates is within normal limits, but the content of ammonium salt exceeds the MPC up to 20 times in the village Kopystyn and from 2 to 7 times in the village of Letychiv. According to many indicators of the salt block, the maximum concentration limit was not exceeded, except for the village Kopystyn, the concentration of Magnesium $(\mathrm{Mg})$ was $84.33 \mathrm{mg} / \mathrm{dm}^{3}$ at a rate of $40.00 \mathrm{mg} / \mathrm{dm}^{3}$. According to specific toxic substances, the water belonged to the III class 4 quality category, Chromium (Cr) was not detected, Manganese (Mn) and Copper (Cu) were within normal limits, although the Copper content was high. The concentration of Iron (Fe) varies in different areas and during the year, there is a case of excess Iron in the village. Kopistin up to $0.86 \mathrm{mg} / \mathrm{dm}^{3}$ at a rate of $0.30 \mathrm{mg} / \mathrm{dm}^{3}$. Iron affects the intensity of phytoplankton development and the qualitative composition of the microflora, so its concentration is subject to seasonal fluctuations. To improve the quality of water in the Southern Bug River, we have proposed the use of biotechnological methods, including those that provide many opportunities to effectively address issues related to monitoring, assessment, and treatment of polluted watercourses.

Key words: Southern Bug River, Maryanivske Reservoir, Kopystyn, Shchedrivske Reservoir, quality indicators, salt composition, specific toxic substances, biotechnological methods of water purification. 


\title{
Оцінка якості вод Південного Бугу в межах Хмельницької області та біоте- хнологічні шляхи вирішення їх очищення
}

\author{
О. О. Малащук, О. П. Руденко
}

Львівський національний університет ветеринарної медицини та біотехнологій імені С. 3. Гжиџького, м. Львів, Украӥна

Водні ресурси є національним багатством кожної держави, важливим природним ресурсом і визначають можливості розвитку більшості галузей господарського комплексу Украйни. Річка Південний Буг є найбільшою річкою, басейн якої повністю розташований на території Украӥни. Внаслідок інтенсивного зростання антропогенного виливу на досліджувану водойму та господарського використання ї̈ ресурсів значно знизилась якість води у ній. Для поліпшення якості вод у річках оптимальним $\epsilon$ використання біотехнологічних методів, щз дають безліч можливостей для ефективного вирімення питань, які стосуються моніторингу, оиінки та обробки забруднених водних потоків. Мета нашого дослідження полягала в оцінюванні безпеки води, сучасного екологічного стану річки Південного Бугу в межах Хмельнищької області у трьох створах (Мар'янівське водосховище, с. Копистин, Щедрівське водосховище) та використання у побутових потребах, з аналізом потениійних ризиків для здоров'я людини, розроблення нових біотехнологічних та удосконалення існуючих заходів для поліпшення водозабезпечення населення. Експериментальна частина роботи виконувалась на базі Хмельницького обласного управління водних ресурсів у лабораторії за адресою м. Хмельницький, вул. Соборна, 29. Нами була проведена хімічна оиінка річки Південного Бугу за трьома показниками: сольовим складом (II), трофо-сапробіологічним (I2) $і$ специфічними речовинами токсичної діï (I3). Дослідження річкових вод проводили з метою контролю ГДК (гранично допустимих концентрачіiі) речовин для використання у побутових та харчових потребах населення та запропонувати біотехнологічні методи очищення річкової води у межах Хмельницької області. Згідно з проведеними нами дослідженнями за гідрохімічними характеристиками вода містила підвищений рівень $\mathrm{NH}_{4}, \mathrm{NO}_{2}, \mathrm{NO}_{3}, \mathrm{PO}_{4}$, середні значення ХСК (хімічне споживання кисню) перевищувало ГДК у всіх створах від 2 до 5 разів. Це може бути наслідком впливу органічних сполук природного походження. Вміст нітритів, нітратів перебуває в межсах норми, але вміст амонію сольового перевищує ГДК до 20 разів в с. Копистин та від 2 до 7 разів в смт Летичів. За багатьма показниками сольового блоку перевищення ГДК не відбувалося, окрім с. Копистин,

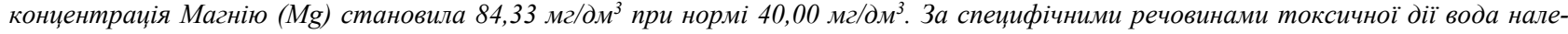
жала до III класу 4 категорії якості, Хром (Cr) не виявлений, показники Мангану (Mn) та Міді (Си) в межах норми, хоча вміст Міді високий. Концентрація Заліза (Fe) змінюється у різних ділянках і протягом року, є випадок перевищення Заліза в с. Копистин

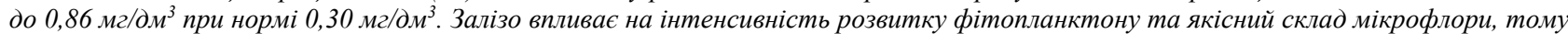
його концентрація схильна до сезонних коливань. Для поліпшення стану якості вод у річиі Південний Буг нами запропоновано використання біотехнологічних методів, зокрема таких, які дають безліч можливостей для ефективного вирішення питань, щэо стосуються моніторингу, оцінки та обробки забруднених водних потоків.

Ключові слова: річка Південний Буг, Мар'янівське водосховище, с. Копистин, Щедрівське водосховище, якісні показники, сольовий склад, спечифічні речовини токсичної дії, біотехнологічні методи очищення води.

\section{Вступ}

Внаслідок інтенсивного зростання антропогенного впливу та використання ресурсів річки Південний Буг значно знизилась якість води. Надмірне будівництво штучних водойм, надходження неочищених стоків зливових каналізації, зростання надходження залишків пестицидів і мінеральних добрив призводять до погіршення якості води. Висока розораність земель, надмірна насиченість їх просапними культурами, недостатня залуженість й залісненість водозборів посилюють ерозійні процеси, забруднюють й замулюють Південний Буг (Vyshnevskyi, 2000; Boiaryn, 2006; Afanasiev et al., 2012).

Оцінка якості води дозволяє оцінити сучасний стан води і з'ясувати зміни їі стану, дає можливість виявити основні проблеми, визначити вплив антропогенного навантаження та обгрунтувати рекомендації для поліпшення екологічного стану води і визначити шляхи очищення, що є актуальним завданням сьогодення (Denysyk, 2006; Prodanchuk et al., 2006; Hovorun \& Tymoshchuk, 2010; Zhemerov, 2011; Rudenko et al., 2019; 2021).

Тому метою нашої роботи було визначення оцінки сучасного екологічного стану вод річки Південний Буг в межах Хмельницької області у трьох створах: Мар'янівське водосховище (смт Чорний Острів), с. Копистин (нижче від м. Хмельницького), Щедрів- ське водосховище (нижче від с. Щедрове Летичівського району) з аналізом потенційних ризиків для здоров'я людини та господарських потреб, як основи для подальшого розроблення нових біотехнологічних та удосконалення існуючих заходів та поліпшення водозабезпечення населення.

Поліпшення якості питної води є пріоритетним завданням у контексті сталого розвитку держав, що задекларовано в рішеннях $\mathrm{OOH} з$ проблем навколишнього середовища. Актуальність вирішення даної проблеми зростає у зв'язку з тим, що 70 \% населення використовує поверхневі води Південного Бугу для питних потреб (Trokhymenko \& Mahas, 2009; Lukianova, 2016).

\section{Матеріал і методи досліджень}

Експериментальна частина роботи виконувалась на базі Хмельницького обласного управління водних ресурсів у лабораторії за адресою м. Хмельницький, вул. Соборна, 29.

Відбір матеріалу проводили відповідно до вимог ДСанПіНу N 383/1940 “Вода питна. Гігієнічні вимоги до якості води централізованого господарськопитного водопостачання". Приготування необхідних розчинів проводилося згідно з методичними вказівками "Екологічна оцінка якості поверхневих вод за відповідними категоріями”, розроблено відповідно до 
Закону України "Про охорону навколишнього природного середовища", "Водного кодексу України”, постанови Кабінету Міністрів України від 19 березня 1997 р. № 2.

Процедура виконання екологічної оцінки складалася 3 таких етапів: групування та обробка вихідних даних, визначення класів і категорій якості за окремими показниками, узагальнення i визначення об'єднаної оцінки якості води.

Оцінка якості води здійснювалась у таких пунктах спостережень: Мар'янівське водосховище, смт Чорний Острів, с. Копистин, нижче від м. Хмельницького, с. Щедрове Летичівського району.

Вихідні дані відповідно до "Методики екологічної оцінки якості поверхневих вод за відповідними категоріями" було згруповано в три блоки: сольовий склад $\left(\mathrm{I}_{1}\right)$; трофо-сапробіологічні показники $\left(\mathrm{I}_{2}\right)$; специфічні речовини токсичної дії $\left(\mathrm{I}_{3}\right)$ (Romanenko et al., 1998; Yatsyk, 2004; Netrobchuk \& Boiaryn, 2008; Afanasiev et al., 2012).

Розрахунки проводять в межах кожного $з$ трьох блоків $\left(\mathrm{I}_{1}, \mathrm{I}_{2}, \mathrm{I}_{3}\right)$ та визначають інтегральну $\left(\mathrm{I}_{\mathrm{E}}\right)$ екологічну характеристику за формулою:

$$
I e=\frac{I_{1}+I_{2}+I_{3}}{3}
$$

За якістю поверхневих вод розрізняють вісім категорій, які базуються на узагальнюючих ознаках: I відмінна, II - добра, III - досить добра, IV - задовіль- на, V - посередня, VI - погана, VII - дуже погана, VIII - занадто погана (Boiaryn, 2006; Yatsyk, 2012).

За ступенем забруднення категорії якості води характеризують як I - дуже чисту, II - чисту, III - досить чисту, IV - слабко забруднену, V - помірно забруднену, VI - сильно забруднену, VII - брудну, VIII - дуже брудну (Khilchevskyi et al., 2009; Yatsyk, 2012).

\section{Результати та їх обговорення}

За багатьма показниками сольового блоку перевищення ГДК не відбувалося. У середньому мінералізація води становить 637,6 мг/дм³ (див. табл. 1) і характеризується як жорстка. За довжиною річки величина мінералізації майже не змінюється. Згідно з дослідженням воду можна охарактеризувати як солонувату - II класу якості, $a$-мезогалинну - 4 категорії якості. За критеріями іонного складу вода Південного Бугу у Хмельницькій області належать до гідрокарбонатного класу, групи Кальцію II типу. Велика кількість Кальцію може надходити зі стічними водами підприємств і з сільськогосподарських угідь, при застосуванні мінеральних добрив, що містять Кальцій. Якість води відповідає класу “добра", за ступенем чистоти “досить чиста”. За середніми значеннями найгірший індекс забруднення - 3,5 спостерігали у с. Копистин, а найменший індекс - 2,2 забруднення у Щедрівському водосховищі.

\section{Таблиця 1}

Екологічна оцінка якості води за сольовим складом

\begin{tabular}{|c|c|c|c|c|c|c|c|c|c|c|c|}
\hline \multirow{2}{*}{$\frac{\text { Пункт }}{\text { Мар'янівське }}$} & \multirow{2}{*}{$\begin{array}{c}\begin{array}{c}\text { Концент- } \\
\text { рація }\end{array} \\
\text { середня }\end{array}$} & \multicolumn{2}{|c|}{$\begin{array}{c}\text { Сума іонів } \\
\text { мг/дм }{ }^{3}\end{array}$} & \multicolumn{2}{|c|}{$\begin{array}{c}\mathrm{SO}_{4} \\
\mathrm{M \Gamma} / \text { дм }^{3}\end{array}$} & \multicolumn{2}{|c|}{$\begin{array}{c}\mathrm{Cl} \\
\mathrm{M \Gamma} / \mathrm{дM}^{3}\end{array}$} & \multicolumn{2}{|c|}{$\begin{array}{c}\text { Мініралізація } \\
\text { г/дм }{ }^{3} \%^{0} \\
\end{array}$} & \multirow{2}{*}{$\begin{array}{l}\text { Іон. } \\
\text { Склад } \\
C^{C a} a_{I I I}\end{array}$} & \multirow{2}{*}{$\begin{array}{l}\mathrm{I}_{1} \\
3\end{array}$} \\
\hline & & 651,83 & $\mathrm{II}(2)$ & 91,46 & II (3) & 51,2 & II(3) & 8,83 & II(4) & & \\
\hline водосховище & максим & 843,1 & $\mathrm{II}(3)$ & 153,6 & $\operatorname{III}(5)$ & 107, & III(4) & 10,84 & II(4) & $\mathrm{C}^{C a}{ }_{I I I}$ & 4 \\
\hline \multirow{2}{*}{ с. Копистин } & середня & 808,7 & II(3) & 76,61 & $\mathrm{II}(3)$ & 82,0 & III(4) & 7,88 & II(4) & $\mathrm{C}^{\mathrm{Ca}}{ }_{I}$ & 3,5 \\
\hline & максим & 1007 & $\operatorname{III}(4)$ & 91,69 & II(3) & 101 & III(4) & 8,72 & II(4) & $\mathrm{C}^{\mathrm{Ca}}{ }_{I}$ & 3,7 \\
\hline Щедрівське & середня & 452,7 & $\mathrm{I}(1)$ & 37,45 & $\mathrm{I}(1)$ & 43,5 & II(3) & 5,04 & II(4) & $\mathrm{C}^{C a}{ }_{I I}$ & 2,2 \\
\hline водосховище & максим & 522,4 & $\mathrm{II}(2)$ & 54,87 & $\mathrm{II}(2)$ & 47,0 & II(3) & 5,92 & II(4) & $\mathrm{C}^{C a}{ }_{I I}$ & 2,7 \\
\hline \multirow{2}{*}{ Загальна оцінка } & середня & 637,6 & $\mathrm{II}(2)$ & 68,50 & $\mathrm{II}(2)$ & 58,9 & II(3) & 7,25 & II(4) & $\mathrm{C}^{C a}{ }_{I I}$ & 2,9 \\
\hline & максим & 790,8 & $\mathrm{II}(3)$ & 100 & II (3) & 85 & $\mathrm{III}(4)$ & 8,93 & $\mathrm{II}(4)$ & $\mathrm{C}^{C a}{ }_{I I}$ & 3,4 \\
\hline
\end{tabular}

За гідрофізичними і гідрохімічними характеристиками вода належить до III класу, якості - “задовільна”, категорії - 4, ступенем забрудненості - “слабко забрудненна", евтрофна, $\beta$ - езосапробної зони. Річкова вода характеризується підвищеним вмістом органічних сполук, середні значення ХСК перевищували ГДК у всіх створах від 2 до 5 разів.

Підвищений вміст органічних сполук $є$ наслідком впливу органічних сполук природного походження, що надходять у води $з$ торфовищ та боліт, і низької водності.

Вміст нітритів, нітратів перебуває в межах норми, але вміст амонію сольового перевищує ГДК до 20 разів в с. Копистин та смт Летичів від 2 до 7 разів (див. табл. 2). Концентрація кисню надзвичайно низька, що погано впливає на всі живі організми, зниження вмісту спостерігається після м. Хмельницького. Збільшення вмісту амонію та фосфатів, завислих речовин у с. Копистин і смт Летичів, зміна кольоровості води по всіх створах свідчить про цвітіння води, що є наслідком забруднення води. Згідно з результатами у створі с. Копистин в більшості показників простежується зростання їх концентрацій, де якість води знизилась до 5 класу “задовільна” зі ступенем чистоти - “помірно забруднена".

На зниження якості води може впливати діяльність підприємства “Хмельницькводоканал”. 
Таблиця 2

Оцінка якості річкової води за гідрофізичними і гідрохімічними показниками

\begin{tabular}{|c|c|c|c|c|c|c|c|c|c|c|}
\hline & $\begin{array}{c}\text { Завис. речов. } \\
\text { мг/дм }{ }^{3}\end{array}$ & $\begin{array}{l}\text { Прозо- } \\
\text { рість, м }\end{array}$ & $\mathrm{pH}$ & $\begin{array}{c}\mathrm{NH}_{4} \\
\text { мг } \mathrm{N} / д м^{3} \\
\end{array}$ & $\begin{array}{c}\mathrm{NO}_{2} \\
\text { мг } / \mathrm{N}_{\text {дм }}{ }^{3} \\
\end{array}$ & 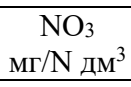 & $\begin{array}{c}\mathrm{PO}_{4} \\
\mathrm{M \Gamma} / \mathrm{N}^{2} \mathrm{M}^{3} \\
\end{array}$ & $\begin{array}{c}\text { Розчин. } \\
\mathrm{O}_{2} \text { мг/дм }{ }^{3} \\
\end{array}$ & 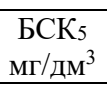 & $\mathrm{I}_{2}$ \\
\hline $\begin{array}{l}\text { Мар'янівське } \\
\text { водосховище }\end{array}$ & 15,17 & 0,266 & 7,82 & 0,705 & 0,21 & 0,24 & 0,13 & 6,55 & 6,50 & \\
\hline Категорія & II (3) & I (1) & $\mathrm{II}(2)$ & $\mathrm{III}(5)$ & $\mathrm{V}(7)$ & II (2) & III(5) & III(4) & $\mathrm{III}(5)$ & 3,7 \\
\hline с. Копистин & 25,10 & 0,276 & 8,22 & 14,46 & 0,25 & 0,65 & 1,85 & 3,71 & 8,92 & \\
\hline Категорія & III (4) & I (1) & $\mathrm{III}(4)$ & $\mathrm{V}(7)$ & $\mathrm{V}(7)$ & $\operatorname{III}(4)$ & $\mathrm{V}(7)$ & $\mathrm{V}(7)$ & IV(6) & 5,2 \\
\hline $\begin{array}{l}\text { Щедрівське } \\
\text { водосховище }\end{array}$ & 35,60 & 0,267 & 8,61 & 1,58 & 0,03 & 0,03 & 0,56 & 8,05 & 3,84 & \\
\hline Категорія & III (5) & $\mathrm{I}(1)$ & IV(6) & IV(6) & III (5) & $\operatorname{IV}(6)$ & $\mathrm{V}(7)$ & $\mathrm{I}(1)$ & $\mathrm{V}(7)$ & 4,8 \\
\hline
\end{tabular}

За специфічними речовинами токсичної дії вода належить до III класу, 4 категорії якості, хром не виявлений, показники Марганцю та Міді в межах норми, хоча вміст Міді високий, але вона може надходити стічними водами з сільськогосподарських угідь. Концентрація Заліза змінюється у різних ділянках протягом років, $\epsilon$ випадок перевищення Заліза в с. Копистин до 0,86 мг/дм³ (див. табл. 3) при нормі -
0,30 мг/дм³. Залізо впливає на інтенсивність розвитку фітопланктону та якісний склад мікрофлори, тому його концентрація схильна до сезонних коливань. Наявність Цезію-137 і Стронцію-90 в межах норми, найбільша концентрація за максимальними значеннями була у 2,88 пКі/дм ${ }^{3}$ i 17,10 пКі/дм³ відповідно при нормі 54 пКі/дм ${ }^{3}$.

Таблиця 3

Оцінка вод річки Південний Буг за речовинами токсичної дії

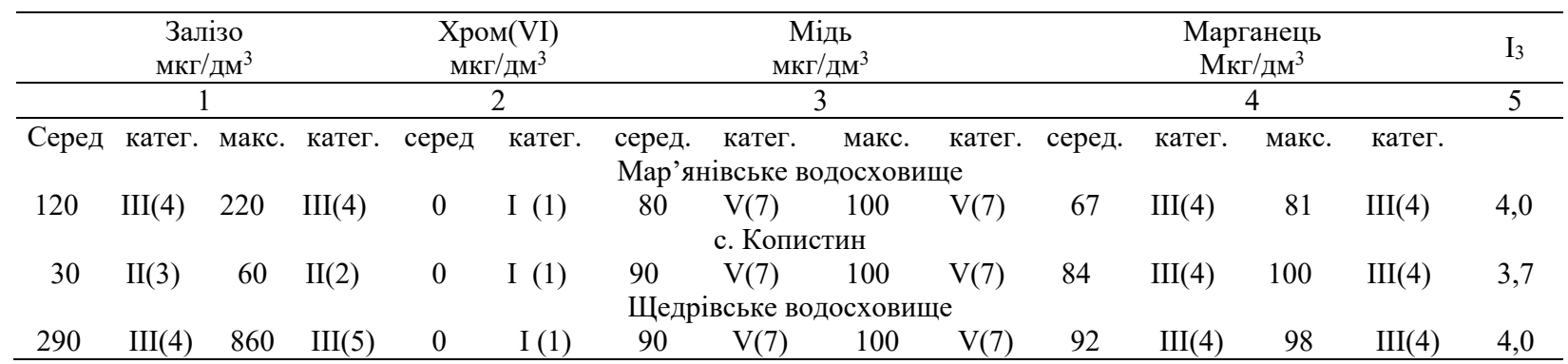

Отже, на території Хмельницької області в річці Південний Буг якість води належить до III класу, 4 категорії, задовільного стану, слабко забруднена (див.

рис. 2). Найбільший внесок у сумарне забруднення води належить гідрофізичним і гідрохімічним показникам, найменший показник сольового складу.

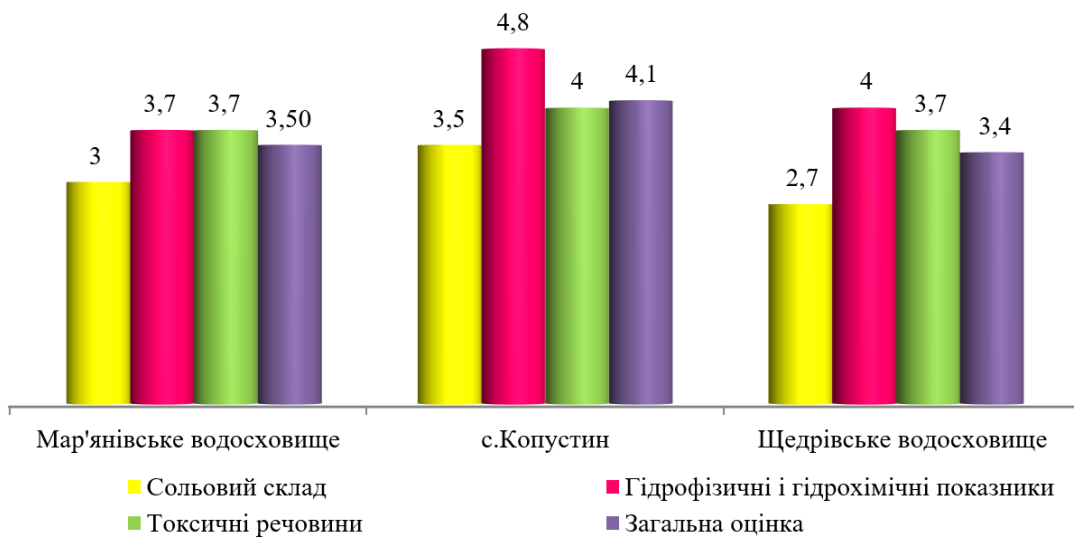

Рис. 2. Екологічна оцінка якості води річки Південний Буг за блоковими індексами $\mathrm{I}_{1}, \mathrm{I}_{2}, \mathrm{I}_{3}$ у трьох створах

Найбільш забрудненою вода виявилася у с. Копистин, нижче від міста Хмельницького, яка зарахована до III класу за станом “задовільна", за ступенем чистоти “слабко забруднена", 3 індексом загальної оцінки - 4.1.

За середніми значеннями показників найкращий екологічний стан в Щедрівському і Мар'янівському водосховищі, де якість води II класу за станом “добра", за ступенем чистоти “досить чиста", індекс загальної оцінки - 3,4.

Згідно 3 проведеними дослідженнями, нашими пропозиціями щодо очищення найбільш забруднених вод Південного Бугу в с. Копистин будуть: 
-здійснення очищення річкової води біологічним методом очистки;

-інтенсифікація процесів біологічного очищення за рахунок введення носіїв 3 іммобілізованими мікроорганізмами (Sablii, 2013).

Одним із раціональних способів є біологічне очищення як один з головних етапів очистки. Суть цього методу полягає в біохімічному окисленні органічних речовин мікроорганізмами.

В біологічному очищенні води, забрудненої органічними речовинами, надзвичайно велика роль належить живим організмам, особливо бактеріям. Проте суттєвих успіхів в очистці води можна досягти за умови використання не лише бактерій, а максимально широкого кола гідробіонтів-очисників, починаючи 3 бактерій та водоростей та закінчуючи хребетними, як це має місце в природних гідроценозах (Hvozdiak, 2003).

Однак при надто високих забрудненнях традиційні методи з використанням аеротенків не завжди можуть задовольнити необхідні показники очищення стічної води підприємств тваринництва. Тому пропонується інтенсифікація процесів біологічного очищення за рахунок введення носіїв з іммобілізованими мікроорганізмами (Sablii, 2017).

Доведено, що такі гідробіонти є більш стійкими та ефективними порівняно з вільноплаваючим активним мулом.

Особливість нової технології - багатоступеневе анаеробно-аеробне очищення вод 3 використанням іммобілізованих мікроорганізмів. Основні переваги: можливість підвищити ефективність очищення вод від високомолекулярних органічних і неорганічних речовин, зменшення надходжень токсичних речовин (Das \& Adholeya, 2015).

Використання саме іммобілізованих або інкапсульованих різним способом мікроорганізмів вважається більш ефективним, ніж застосування вільних клітин, оскільки це призводить до більш високого завантаження біомаси, легшої роботи на межі тверда речовина - рідина, вищої швидкості біодеградації та забезпечення кращої стабільності роботи, суттєвого захисту від токсичних речовин, підвищеної стабільності плазмід у складі іммобілізованих клітин (Martins et al., 2013).

\section{Висновки}

Загальна екологічна оцінка стану вод Південного Бугу у межах Хмельницької області здійснювалася на основі "Методик екологічної оцінки", нами встановлено, що середніми значеннями інтегральних індексів не були перевищені показники ГДК.

1. Якість води належить до III класу, 4 категорії, задовільного стану, слабко забруднена. Великий внесок у сумарне забруднення води складають гідрофізичні і гідрохімічні показники. Перевищували норми досліджувані показники води у с. Копистин, яка зараховується до III класу за станом "задовільна", за ступенем чистоти “слабко забруднена";

2. Нами встановлено кращий екологічний стан річкової води в Щедрівському і Мар'янівському водос- ховищі, де якість води II класу за станом “добра”, за ступенем чистоти “досить чиста" - за даними моніторингу Хмельницького регіонального центру водних ресурсів.

Таким чином, в різних ділянках вода у річці Південний Буг має різну якість, і для очищення ііі потрібно використати запропоновані біотехнологічні методи.

\section{References}

Afanasiev, S. O., Vasylchuk, T. O., Lietytska, O. M., \& Bilous, O. P. (2012). Otsinka ekolohichnoho stanu richky Pivdennyi Buh u vidpovidnosti do vymoh Vodnoi Dyrektyvy R YeS: Instytut hidrobiolohii NAN Ukrainy (in Ukrainian).

Boiaryn, M. V. (2006). Intehralnyi ekolohichnyi indeks ekosystemy baseinu richky Zakhidnyi Buh. Nauk. visn. VDU im. Lesi Ukrainky. Eriia: Heohraf. nauky, 2006, 171-177 (in Ukrainian).

Das, M., \& Adholeya, A. (2015). Potential Uses of Immobilized Bacteria, Fungi, Algae, and Their Aggregates for Treatment of Organic and Inorganic Pollutants in Wastewater. Water Challenges and Solutions on a Global Scale. 15, 319-337. doi: 10.1021/bk-20151206.ch015.

Denysyk, H. I. (2006). Pryrodnycha heohrafiia Podillia: EkoBiznesTsentr, 67-74 (in Ukrainian).

Hovorun, V. D., \& Tymoshchuk, O. O. (2010). Richky Khmelnychchyny. Navch. posib. Polihrafist (in Ukrainian).

Hvozdiak, P. I. (2003). Za pryntsypom biokonveiera. Biotekhnolohiia okhorony dovkillia. Visnyk NAN Ukrainy, 3, 29-36 (in Ukrainian).

Karpova, H., Zub, L., Melnychuk, V., \& Protsiv, H. (2010). Otsinka ekolohichnoho stanu vodoim metodamy bioindykatsii. Pershi kroky do otsinky yakosti vody: posibnyk: INEKO, Ekolohichnyi klub "Krai" (in Ukrainian).

Khilchevskyi, V. K., Chunarov, O. V., \& Romas, M. I. (2009). Vodni resursy ta yakist richkovykh vod basseinu Pivdennoho Buhu; za red. Khilchevskoho V. K.: Nika-Tsentr (in Ukrainian).

Kostiushyn, V., Kuzemko, A., \& Onyshchenko, V. (2007). Pivdenno-Buzkyi merydionalnyi ekolohichnyi korydor: styslyi ohliad bioriznomanittia ta naitsinnishi terytorii. Chornomorska prohrama Verlands Interneshnl (in Ukrainian).

Lukianova, L. B. (2016). Laboratornyi praktykum z ekolohii: navch.-metod. posib. (in Ukrainian).

Martins, S. C. S., Martins, C. M., Cidrão Guedes Fiúza, L. M., \& Santaella, S. T. (2013). Immobilization of microbial cells: A promising tool for treatment of toxic pollutants in industrial wastewater. African Journal of Biotechnology, 12(28), 4412-4418. doi: 10.5897/AJB12.2677.

Netrobchuk, I. M., \& Boiaryn, M. V. (2008). Ekolohichna otsinka suchasnoho stanu yakosti vody richky Studianka. Pryroda Zakhidnoho Polissia ta prylehlykh terytorii: zb. nauk. pr. Volyn. nats. un-t im. Lesi Ukrainky, 31-36 (in Ukrainian). 
Prodanchuk, M. H., Mudryi, I. V., \& Velykyi, V. I. (2006). Naukovo-metodychni aspekty toksykolohoklinichnykh doslidzhen vplyvu mineralnoho skladu pytnoi vody na stan zdorovia naselennia Ukrainy. Sovremennye problemy toksykolohii, 3, 4-7. URL: https://scholar.google.com/scholar?cluster=119396022 27861470078\&hl=en\&oi=scholarr (in Ukrainian).

Romanenko, V. D., Zhukynskyi, V. M., Oksiiuk, O. P., \& Yatsyk, A. V. (1998). Metodyka ekolohichnoi otsinky yakosti poverkhnevykh vod za vidpovidnymy katehoriiamy. Kyiv : Symvol-T (in Ukrainian).

Rudenko, O. P., Paranjak, R. P., Kovalchuk, N. A., Kit, L. P., Hradovych, N. I., Gutyj, B. V., Kalyn, B. M., Sukhorska, O. P., Butsiak, A. A., Kropyvka, S. I., Petruniv, V. V., \& Kovalska, L. M. (2019). Influence of seasonal factors on carp fish immune reactivity. Ukrainian Journal of Ecology, 9(3), 168-173. URL: https://www.ujecology.com/articles/influence-ofseasonal-factors-on-carp-fish-immune-reactivity.pdf.

Rudenko, O., Lytvyn, N., \& Gutyj, B. (2021). Assessment of microbiological indicators and monitoring of a sociological survey of the quality of sources in the city of Lviv. Scientific Messenger of LNU of Veterinary Medicine and Biotechnologies. Series: Agricultural Sciences, 23(94), 81-85. doi: 10.32718/nvlvet-a9415.
Sablii, L. A. (2013). Fizyko-khimichne ta biolohichne ochyshchennia vysokokontsentrovanykh stichnykh vod: Monohrafiia. Rivne: NUVHP (in Ukrainian).

Sablii, L. A. (2017). Vprovadzhennia novitnikh biotekhnolohii ochyshchennia stichnykh vod. Kyivskyi politekhnik. Onovleno: 28/03/2017-14:57 (in Ukrainian).

Trokhymenko, H. H., \& Mahas, N. I. (2009). Otsinka yakosti vody osnovnykh prytok richky Pivdennyi Buh u mezhakh Mykolaivskoi oblasti. Naukovyi visnyk MDU im. V.O. Sukhomlynskoho, 209-213 (in Ukrainian).

Vyshnevskyi, V. I. (2000). Richky i vodoimy Ukrainy. Stan i vykorystannia: Vipol (in Ukrainian).

Yatsyk, A. V. (2004). Vodohospodarska ekolohiia: Heneza (in Ukrainian).

Yatsyk, A. V. (2012). Ekolohichna otsinka yakosti poverkhnevykh vod za vidpovidnymy katehoriiamy: metodychni vkazivky do vykonannia praktychnykh zaniat: NUVHP (in Ukrainian).

Zhemerov, O. O. (2011). Otsinka yakosti poverkhnevykh vod sushi: metod. posib. Kharkiv: KhNU im. V.N. Karazi-na (in Ukrainian). 